\title{
Inter-nesting habitat-use patterns of loggerhead sea turtles: enhancing satellite tracking with benthic mapping
}

\author{
Kristen M. Hart ${ }^{1, *}$, David G. Zawada ${ }^{2}$, Ikuko Fujisaki ${ }^{3}$, Barbara H. Lidz ${ }^{2}$ \\ ${ }^{1}$ US Geological Survey, Southeast Ecological Science Center, Davie, Florida 33314, USA \\ ${ }^{2}$ US Geological Survey, St. Petersburg Coastal and Marine Science Center, St. Petersburg, Florida 33701, USA \\ ${ }^{3}$ University of Florida, Ft. Lauderdale Research and Education Center, Davie, Florida 33314, USA
}

\begin{abstract}
The loggerhead sea turtle Caretta caretta faces declining nest numbers and bycatches from commercial longline fishing in the southeastern USA. Understanding spatial and temporal habitat-use patterns of these turtles, especially reproductive females in the neritic zone, is critical for guiding management decisions. To assess marine turtle habitat use within the Dry Tortugas National Park (DRTO), we used satellite telemetry to identify core-use areas for 7 loggerhead females internesting and tracked in 2008 and 2009. This effort represents the first tracking of DRTO loggerheads, a distinct subpopulation that is 1 of 7 recently proposed for upgrading from threatened to endangered under the US Endangered Species Act. We also used a rapid, high-resolution, digital imaging system to map benthic habitats in turtle core-use areas (i.e. $50 \%$ kernel density zones). Loggerhead females were seasonal residents of DRTO for 19 to $51 \mathrm{~d}$, and individual inter-nesting habitats were located within $1.9 \mathrm{~km}(2008)$ and $2.3 \mathrm{~km}(2009)$ of the nesting beach and tagging site. The core area common to all tagged turtles was $4.2 \mathrm{~km}^{2}$ in size and spanned a depth range of 7.6 to $11.5 \mathrm{~m}$. Mapping results revealed the diversity and distributions of benthic cover available in the core-use area, as well as a heavily used corridor to/from the nesting beach. This combined tagging-mapping approach shows potential for planning and improving the effectiveness of marine protected areas and for developing spatially explicit conservation plans.
\end{abstract}

KEY WORDS: Dry Tortugas - Caretta caretta $\cdot$ Marine protected area $\cdot$ MPA $\cdot$ Marine spatial planning · Satellite telemetry $\cdot$ Benthic cover $\cdot$ Habitat mapping $\cdot$ Fixed-kernel density estimator

\section{INTRODUCTION}

In recent years, satellite-telemetry studies have increased our understanding of the spatial habitat-use patterns of marine turtles, including nesting behavior (reviewed in Godley et al. 2008, Hart \& Hyrenbach 2009). Most of the focus has been on tracking females post-nesting to determine regional linkages between nesting beaches and foraging grounds, as well as zones of overlap with fishing activities. For example, Seminoff et al. (2008) compared tracks of post-nesting female green turtles Chelonia mydas in the Galapagos using a variety of remotely sensed oceanographic vari- ables (e.g. sea-surface temperature [SST], SST front locations, surface height anomaly, surface current, and surface chlorophyll a concentration) to determine potential environmental influences on turtle movements and identify likely migration corridors. Fossette et al. (2009) investigated thermal and trophic conditions encountered by the critically endangered leatherback sea turtle Dermochelys coriacea during its nesting season in French Guiana, where high fisherybycatch rates have been reported. Girard et al. (2009) examined post-nesting routes of loggerheads Caretta caretta in southwestern Florida to determine the destinations of individuals, as well as their use of the 
western Florida shelf. Such information is extremely useful for re-evaluating fishing regulations to minimize impacts to federally threatened and endangered marine turtles (National Marine Fisheries Service \& US Fish and Wildlife Service 2008, National Marine Fisheries Service 2010).

A generally accepted life-history model for Atlantic loggerheads proposes that every 2 to $5 \mathrm{yr}$, females make reproductive migrations to breed and nest in the vicinity of their natal beach (Plotkin 2003). During the nesting season, females deposit multiple clutches of eggs on the beach at $\sim 2$ wk intervals throughout the season (Addison 1996, Sato et al. 1998, Hays et al. 2002, Schroeder et al. 2003). Turtles then travel back to their foraging sites, to which they also show a high level of fidelity (Limpus et al. 1992, Plotkin 2003, Schroeder et al. 2003, Broderick et al. 2007, Girard et al. 2009). These sites can be relatively nearby or hundreds to thousands of kilometers away from each other.

To date, only a few satellite-tracking studies of nesting marine turtles have characterized loggerhead movements during the period between nesting events, i.e. the inter-nesting period, in the southwest Atlantic (southern Georgia: Stoneburner 1982, Virginia: Bartol \& Musick 1998, Georgia: Plotkin \& Spotila 2002, eastcentral Florida: Dodd \& Byles 2003) or the Caribbean (Blumenthal et al. 2006). These studies found that females typically remained within the vicinity of a nesting beach during the inter-nesting period, but, in most cases, turtles were tagged at the end of the nesting season. Of these previous satellite-tracking studies, Dodd \& Byles (2003) conducted their work closest to south Florida. One of their 4 turtles was tagged in the middle of the nesting season; however, that turtle did not return to nest after release. Thus, our understanding is limited with respect to the specific local habitats used by adult female loggerheads in this region during the inter-nesting period.

Earlier, in an intense South Carolina study on loggerheads, Murphy \& Hopkins (1981) used underwater acoustic and radio tracking to measure habitat use of females during the nesting season. Their final phase of study in 1979 produced data for 29 loggerheads; results indicated that most inter-nesting turtles used high-relief areas 1 to $10 \mathrm{~m}$ in depth, but no patterns were documented for depth or bottom type during the nesting season. However, Murphy \& Hopkins (1981) were among the first to report detailed observations of concentrated turtle activities in limited core areas (further described in Hopkins-Murphy et al. 2003). Building on this idea, Houghton et al. (2002) hypothesized that the inter-nesting behavior of marine turtles is driven by the optimization of energy reserves in a manner most suited to localized conditions and to the processes associated with nesting (i.e. a turtle's ability to relocate the nesting site). In a review of loggerhead nesting patterns, reproductive migrations, and adult foraging areas, Schroeder et al. (2003) summarized that most seasonal nest locations of individual turtles were located within $5 \mathrm{~km}$ of previous nests.

Since the Murphy \& Hopkins (1981) study, few studies have sought to identify the habitats used by reproductive females during the critical time period between nesting at different sites within the species' range. Hays et al. (1991) tracked 1 loggerhead during inter-nesting to infer patterns of movement near the Greek island of Kefalonia. Later, Godley et al. (2003) tracked 1 loggerhead in the Mediterranean during an inter-nesting period. In that study, the authors received insufficient locations for examining the turtle's route but did show her to be in the vicinity of the nesting beach for $12 \mathrm{~d}$ following deployment. More recently, Zbinden et al. (2007) utilized satellite telemetry to locate loggerhead inter-nesting areas off the coast of Greece. In that largest-known Mediterranean rookery, they found that turtles showed no obvious preference for the highly protected area of the Bay of Laganas. In that same study area, most recently Schofield et al. (2007, 2009) examined the fine-scale movements of male and female loggerheads within this major breeding rookery using GPS tracking units. Schofield et al. (2010) also used GPS tracking units to document interannual variability in home ranges of breeding turtles at this Mediterranean site and tied those high-resolution results to future marine conservation management, specifically for selection and delineation of marine conservation areas. In another study on leatherbacks, Witt et al. (2008) assessed turtle-habitat utilization during inter-nesting in a national park of Gabon that encompassed a marine protected area (MPA). In that study, turtles dispersed widely from the nesting beach, spending a mean of $62 \%$ of tracking time outside the park boundary. These studies illustrate that providing adequate protection to marine turtles from in-water threats during their entire inter-nesting period requires knowledge of both broad-and fine-scale turtle habitat-use patterns.

Although progress has been made in our understanding of marine turtle use of terrestrial areas for nesting, our understanding is poorly developed regarding both the location and temporal-use patterns of in-water inter-nesting habitats. Moreover, almost nothing is known about the benthic-habitat types contained within inter-nesting areas. One recent study addressing this issue used 2 green turtles in the Mediterranean as remote-sensing platforms (Fuller et al. 2009). In that study, animal-borne digital cameras and time-depth recorders (TDRs) were attached to the nesting females. Data from still images and dives indicated that the turtles spent $80 \%$ of their time at depths 
of $\leq 5 \mathrm{~m}$, allowing for development of at-sea time budgets for each individual. Although this approach offers promise for obtaining detailed characterization of in-water habitats used by marine turtles, image quality is out of human control and retrieval of photographic data necessitates recapture of the turtle. Sample sizes are also limited due to costs of equipment and duration of battery life.

Because few attempts to date have been made to survey habitat within inter-nesting areas, we sought to use a rapid, digitalimaging system to map the marine habitats we found to be important for loggerheads during internesting in our study site. We used the US Geological Survey (USGS)-developed AlongTrack Reef-Imaging System (ATRIS) to simultaneously acquire high-resolution images of the seafloor, GPS positions, and water depth (Zawada et al. 2008). The resulting images form a permanent record of benthic cover and enable the identification of substrate, habitat, and epibenthic organisms, many to the species level (Lidz et al. 2008).

Here, we investigate 2 aspects of loggerhead habitat-use during inter-nesting in Dry Tortugas National Park (DRTO). We expected

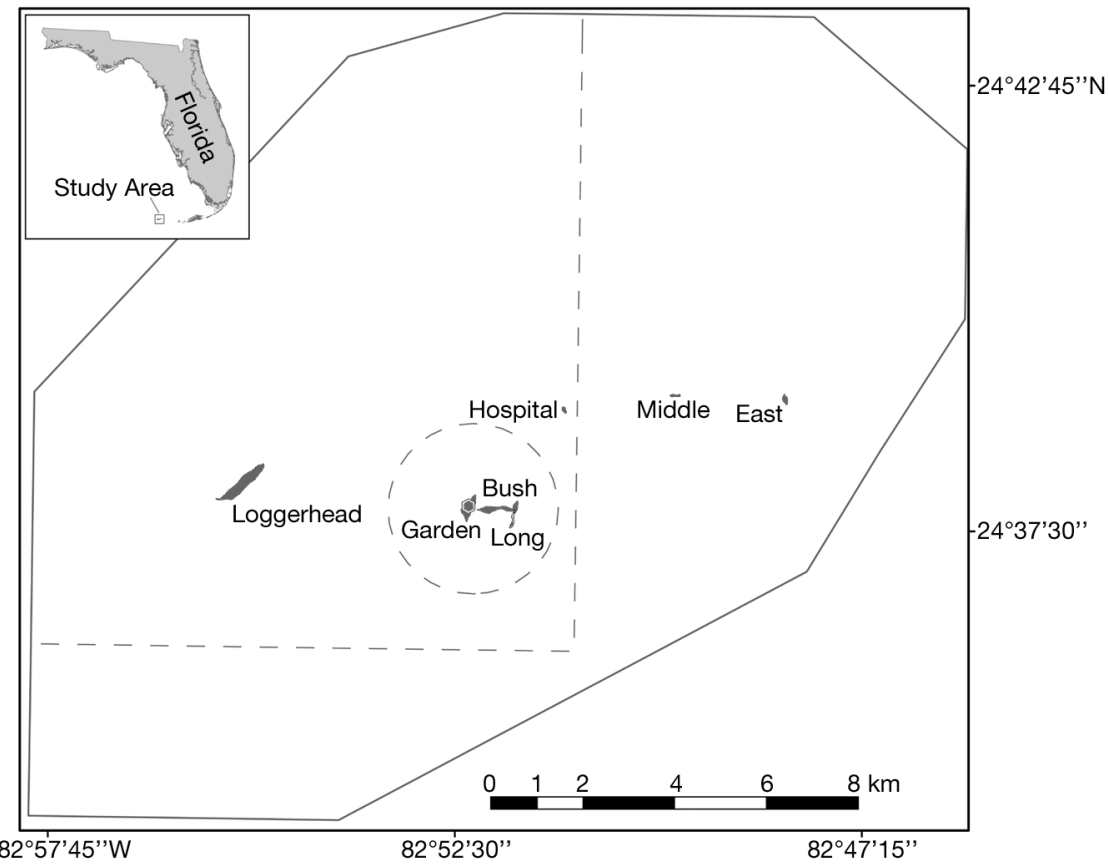

Fig. 1. Dry Tortugas National Park (solid gray lines) is located $\sim 100 \mathrm{~km}$ west of Key West, Florida. The Research Natural Area, a restricted-use zone, lies within the park (dashed gray lines). The circular area surrounding Garden, Bush, and Long Keys is excluded from the Research Natural Area. All turtle interception and tagging took place on East Key that (1) the inter-nesting habitat would be located within $5 \mathrm{~km}$ of the nesting beach, and (2) these areas would offer adequate niches for refuge and possibly resting on the seafloor. Our investigation included determining (1) number of nests per individual and length of inter-nesting periods, (2) site fidelity to the nesting beach, (3) location of core-use areas during the inter-nesting period in 2 consecutive years (2008, 2009), and (4) benthic-habitat cover and depth in the core-use areas.

\section{MATERIALS AND METHODS}

Study site. The Dry Tortugas is a cluster of islands $\sim 100 \mathrm{~km}$ west of Key West, Florida (near 24 38' 00" N, $82^{\circ} 55^{\prime} 12^{\prime \prime} \mathrm{W}$; Fig. 1). The region was designated a Wildlife Refuge in 1908, a National Monument in 1935, and a National Park in 1992. The Dry Tortugas consists of a series of carbonate banks and sand shoals in which the banks roughly form a circular pattern resembling an atoll (Mallinson et al. 2003). Of the 7 islands that make up DRTO, the smallest is East Key, measuring $\sim 400 \mathrm{~m}$ long $\times \sim 100 \mathrm{~m}$ wide. The largest is Loggerhead Key, $\sim 1.5 \mathrm{~km}$ long $\times \sim 250 \mathrm{~m}$ wide. Both islands cap carbonate banks. In January 2007, $74 \mathrm{~km}^{2}$ of the park were designated a Research Natural Area (RNA), creating a no-take preserve to foster ecological self-renewal by minimizing anthropogenic influences (National Park Service 2006). The Research Natural Area complements the adjacent Tortugas Ecological Reserve of the Florida Keys National Marine Sanctuary, established by the National Oceanic and Atmospheric Administration (NOAA) and the State of Florida, and contributes to a region-wide effort to strengthen marine resource protection. The sandy beaches of DRTO are monitored as part of the State of Florida's marine turtle nest monitoring program (e.g. Witherington et al. 2009).

Turtles at DRTO. Although 5 turtle species utilize the park, only loggerhead and green turtles regularly nest on the sandy beaches (Lenihan 1997, Reardon 2000, Van Houtan \& Pimm 2006). Nesting areas (i.e. nonsubmerged lands) include Loggerhead Key, East Key, Bush Key, Long Key, Garden Key, and Hospital Key (Fig. 1; Reardon 2000), but the majority of turtlenesting activity occurs on East and Loggerhead Keys. The Dry Tortugas loggerhead nesting assemblage and its associated nesting beaches are now considered part of the Dry Tortugas Recovery Unit, as defined by the Loggerhead Recovery Team in the US Federal recovery plan (National Marine Fisheries Service \& US Fish and Wildlife Service 2008). Turtle-nest densities on East Key in particular are similar to those of the major turtle colonies in southeast Florida (Van Houtan \& Pimm 2006). Despite being less than one-tenth the size 
of Loggerhead Key, East Key consistently hosts many more nests from year to year, and for this reason, we selected it as our tagging site. In the Tortugas, loggerhead nesting activity occurs from late April through August, peaking in late June and early July.

Loggerhead captures and tagging. We intercepted nesting loggerhead females after they had either finished nesting or had completed their false crawl on East Key. We corralled each turtle to confine her for workup and covered her eyes. We followed established protocols for taking biological samples (National Marine Fisheries Service Southeast Fisheries Science Center 2008). We also individually marked each animal by inserting a passive integrated transponder (PIT) tag in the right shoulder region and affixing individually numbered flipper tags to each trailing-edge front flipper. Immediately after marking each animal, we took standard carapace measurements, including curved (CCL) and straight (SCL) carapace lengths.

We fitted a Wildlife Computers SPOT5 platform terminal transmitter (PTT) to each turtle. Each tag (2.5xAA model) had a salt-water switch, output of $0.5 \mathrm{~W}$, and measured $71 \times 54 \times 24 \mathrm{~mm}$, with a mass of $115 \mathrm{~g}$ in air. Each PTT plus epoxy did not exceed $5 \%$ of the turtle's body weight. Prior to transmitter application with PowerFast $^{\circledR}$ 2-part marine epoxy, we removed epibionts (e.g. barnacles, algae) from the carapace of each turtle and sanded and cleaned the carapace with isopropanol. We streamlined attachment materials to minimize any buoyancy or drag effects on the turtle's swimming ability and limited the epoxy footprint. Each tag was set to be active for $24 \mathrm{~h} \mathrm{~d}^{-1}$. Once tagging was complete, we removed the blindfold and corral, allowing the turtle to return to the sea.

Satellite-data filtering and analysis. We used the satellite-tracking and analysis tool (STAT; Coyne \& Godley 2005) to archive and filter location data. Points were grouped into location classes (LCs) according to decreasing accuracy (i.e. highest to lowest accuracy: LCs 3, 2, 1, 0, A, B, and Z). For purposes of delineating core-use areas and subsequent ATRIS mapping, we used points in LCs 3 through B that remained after filtering with the following removal process: (1) LC Z locations (for which no error estimate is available), (2) locations that required straight-line swimming speeds $>5 \mathrm{~km} \mathrm{~h}^{-1}$, and (3) locations that exceeded elevations of $0.5 \mathrm{~m}$.

To infer nesting events, we filtered data to include the 3 highest-quality LCs (i.e. LCs 3, 2, and 1; Hays et al. 2001, Vincent et al. 2002) and swim speeds of $<5 \mathrm{~km} \mathrm{~h}^{-1}$. We used several criteria in combination to identify each presumed emergence, similar to methods of Tucker (2010): (1) direct verification by nocturnal ground truthing; (2) emergences coinciding within the expected $\sim 2$ wk inter-nesting intervals for loggerheads (Addison 1996, Sato et al. 1998, Hays et al. 2002, Schroeder et al. 2003); (3) high-Argos LCs 3, 2, and 1 within a short time span; (4) evidence of a decreased displacement from shore in Argos LCs 3, 2, and 1 data; and (5) evidence of an increased surface interval in the PTT data. We did not use the genetic, distance, behavioral, or depth criterion outlined by Tucker (2010) due to the small size of the nesting beach at East Key and the lack of an accurate bathymetric map for the area surrounding East Key.

To determine core-use areas, we generated mean daily locations for each turtle from the filtered locations within DRTO to minimize autocorrelation, following methods of Seney \& Landry (2008). The resulting coordinates provided raw data for kernel densityestimation (KDE) analysis across all individuals. Kernel density is a non-parametric method used to identify 1 or more areas of disproportionately heavy use (i.e. core areas) within a home-range boundary (for review, see Worton 1987, 1989, White \& Garrott 1990), with appropriate weighting of outlying observations. We used the Home-Range Tools for ArcGIS extension (Rodgers et al. 2005) and fixed-kernel least-squares cross-validation smoothing factor $\left(h_{c V}\right)$ for each KDE (Worton 1995, Seaman \& Powell 1996). Seaman \& Powell (1996) suggested this approach as the most accurate home-range assessment technique, and since then it has been used to delineate home and core ranges for several species of sea turtles (Seminoff et al. 2002, Seney \& Landry 2008, Hart \& Fujisaki 2009). When the variance of $x$ and $y$ coordinates of the points was highly unequal, the data were rescaled before applying the kernel method. We used ArcGIS 9.3 (ESRI 2007) to calculate the inwater area $\left(\mathrm{km}^{2}\right)$ within each kernel density contour (50 and $95 \%$ ) and to plot the data. We used a 95\% KDE to estimate overall home range of a turtle during the summer inter-nesting period and a $50 \%$ KDE to represent the core area of activity during inter-nesting (Hooge \& Eichenlaub 2000).

We also tested location data for and quantified site fidelity using Animal Movement Analysis Extension for ArcView 3.2. We used Monte Carlo Random Walk simulations to test for site fidelity (100 replicates), testing tracks during inter-nesting for spatial randomness against randomly generated walks (Hooge et al. 2001, Mansfield et al. 2009, Hart \& Fujisaki 2009). Tracks exhibiting site fidelity indicate that the turtles' movements were more spatially constrained rather than randomly distributed (Hooge et al. 2001).

We overlaid DRTO and RNA boundaries on all resulting maps and summed locations in the park. We measured area of resulting 95\% and 50\% KDEs for each turtle using ArcGIS. Following these analyses, we examined only the highest-quality locations (LCs 3, 2, 
1) to assess spatial locations of turtles within the coreuse areas that might indicate turtle use of specific features (i.e. ledges, channels) near the tagging site at East Key. Corresponding depths for turtle locations were extracted from a raster data of water depth based on light-detection and ranging (lidar) data with a $10 \mathrm{~m}$ spatial resolution and a $0.1 \mathrm{~m}$ precision ( $\mathrm{J}$. Luo unpubl.). Using ArcGIS 9.3, we extracted from the raster data water depth at each recorded animal location within DRTO.

We measured distance of core-use areas from the center of the East Key shoreline in ArcView 3.2. We calculated swim speed for each turtle using a linear distance between points in $\mathrm{km} \mathrm{h}^{-1}$, which was the average linear distance moved over time of 2 consecutive filtered locations. We conducted all statistical tests in SAS 9.1 (SAS Institute 1996) and used an $\alpha$-level of 0.05 for all analyses.

Benthic mapping. In June 2009, we conducted benthic surveys using the USGS-developed ATRIS, which simultaneously acquired geo-referenced, color digital images and water-depth measurements. ATRIS can be deployed either from an adjustable pole mounted to the side of a boat ('shallow' configuration) or from a towed vehicle down to depths of $27 \mathrm{~m}$ ('deep' configuration); the same camera and acquisition software are used for both operating modes. We used shallow ATRIS in the present study; Zawada et al. (2008) provide details on the various ATRIS components. ATRIS transect lines were based on the extent of the 2008 loggerhead $50 \% \mathrm{KDE}$, and we mapped inclusive habitats at $1.3 \mathrm{~m} \mathrm{~s}^{-1}$. Camera focus was set at $1.5 \mathrm{~m}$ in air, which equates to $2.0 \mathrm{~m}$ in water, and the aperture was fixed at $\mathrm{f} / 5.6$. At this range, image coverage was $1.03 \mathrm{~m} \times$ $0.78 \mathrm{~m}$ with a resolution of $0.8 \mathrm{~mm}$ pixel $^{-1}$. Exposure times were dynamically determined based on automatic gain control and automatic white-balancing. During sampling, we acquired images at $5 \mathrm{~Hz}$ and, to improve geo-location accuracy, we operated a fixed, landbased GPS receiver throughout the image-collection period. Both the on-board and land-based GPS receivers recorded National Marine Electronics Association standard GPS-fix data, which include a timestamp, latitude, longitude, and altitude above mean sea level at $1 \mathrm{~Hz}$. The landmark GPS data enabled differential correction of the image locations to sub-meter accuracy and corresponding water depths to $\pm 0.15 \mathrm{~m}$.

ATRIS image analysis. Lidz et al. (2008) have shown that content and composition of ATRIS imagery reveal 2 primary sources of benthic-habitat constituents in shallow-reef environments: biogenic (flora and fauna) and geomorphogenic (changes in seascape substrate and relief). Both are pertinent to the choice of terminology for classification, imagery interpretation, and classification assignment. We performed image classifica- tion visually at a rate of $\sim 2 \mathrm{~s}_{\text {image }} \mathrm{e}^{-1}$ using the ATRIS Data Analysis and Processing Tool (ADAPT), an inhouse software product. This program provided a convenient user interface for viewing, annotating, and classifying the digital images. Because adjacent images overlapped by $\sim 70 \%$, we configured ADAPT to display every 5th image by default. For difficult cases, we temporarily toggled this default and viewed sequential images as needed to aid interpretation. We assigned images to 1 of 5 broad, yet descriptive, categories based on predominant substrate type: unclassifiable, seagrass, senile reef, rubble, and sand. Most seagrass areas consisted predominantly of Thalassia testudinum; however, there were also zones with a mixture of T. testudinum and Syringodium filiforme. The term 'senile reef' refers to a coral framework that is no longer accreting but is now capped by a mixed assemblage of sessile benthic organisms (Lidz \& Hallock 2000, Lidz et al. 2006). 'Rubble' consisted primarily of clearly identifiable Acropora cervicornis sticks intermixed with carbonate fragments of other shapes and sizes of indeterminate origins. We assigned any images lacking high-quality discernible features to the 'unclassifiable' category, and noted any biologic, geologic, or anthropogenic (e.g. anchor lines, derelict or 'ghost' lobster traps, etc.) parameters of interest by image number in a journal.

To assess habitat diversity, we grouped classified images into $200 \times 200 \mathrm{~m}$ cells, forming a grid spanning the study site. Cells containing $<50$ images were excluded from further analyses. For each cell, we computed both the inverse of Simpson's index and a dominance metric (modified Shannon's index). The inverse Simpson's index is defined as

$$
H=\frac{1}{\sum_{i=1}^{N} p_{i}^{2}}, p_{i}=\frac{m_{i}}{M}, i=1 . . N ; \quad 1 \leq H \leq N
$$

where $N$ is the total number of habitat types (classification categories) present in a given cell, $M$ is the total number of classified ATRIS images, and $m_{i}$ is the number of ATRIS images in category $i$. $H$ is sensitive to the relative abundance of available habitat types and ranges from 1.0, when only a single habitat is present, to $N$, when all habitats occur in equal proportions (Ricklefs \& Lovette 1999). The 'unclassifiable' images were excluded from the analysis, so $N$ has a maximum value of 4 . Dominance is defined as

$$
D=\ln (N)+\sum_{i=1}^{N} p_{i} \ln \left(p_{i}\right) ; \quad 0 \leq D<\ln (N)
$$

where $N$ and $p_{i}$ are defined as in Eq. (1). $D$ is Shannon's entropy index with the $\ln (N)$ term added to normalize the index and account for the cell-by-cell variability in the number of available habitat types (O'Neill et 
al. 1988). Dominance quantifies the extent to which 1 or a few habitat types dominate a given cell. It ranges from 0 , when all $N$ habitats occur in equal proportions, to $\ln (N)$, when 1 or a few habitat types is predominant.

To investigate turtle-habitat associations, we extracted the highest-quality filtered loggerhead positions (LCs 3, 2, and 1) from the satellite-tracking data set and binned them according to the same grid used for the habitat indices. This procedure yielded the total number of turtle observations per $200 \times 200 \mathrm{~m}$ cell, which we overlaid atop both habitat-index plots.

\section{RESULTS}

\section{Loggerhead turtles}

We intercepted and satellite-tagged 3 nesting loggerheads on East Key (Fig. 1) in May 2008 and 4 in June 2009. Turtles ranged in size from 82.8 to $111.6 \mathrm{~cm}$ $\mathrm{SCL}$ (tip), mean $\pm \mathrm{SD}: 95.1 \pm 8.6 \mathrm{~cm}$ (Table 1$)$.

\section{Turtle tracking and spatial patterns}

In 2008, turtles were resident in DRTO for 42 to $51 \mathrm{~d}$ (mean $\pm \mathrm{SD}: 47.7 \pm 4.9 \mathrm{~d}$ ) before leaving the park (Table 1). In 2009, turtles were resident for 19 to $30 \mathrm{~d}$ (mean \pm SD: $24.8 \pm 5.6 \mathrm{~d}$ ); however, we tagged turtles $\sim 3$ wk later in 2009 .

Turtles in 2008 nested approximately every $12 \mathrm{~d}$, resulting in observed clutch frequencies of 5 to 6 nests ind. ${ }^{-1}$ during tracking in the inter-nesting interval (Table 2). Turtles in 2009 nested approximately every $11 \mathrm{~d}$, resulting in observed clutch frequencies of 3 to 5 nests ind. ${ }^{-1}$ during tracking in the inter-nesting period (Table 2).

Sizes of core-use areas (i.e. 50\% KDEs) during the inter-nesting period ranged from 12.7 to $91.5 \mathrm{~km}^{2}$ $\left(\right.$ Table $1 ;$ mean $\left.\pm \mathrm{SD}: 31.4 \pm 28.1 \mathrm{~km}^{2}\right) ; 1$ individual (95901) occupied a core-use area 3 times larger than the mean. Body size did not correlate with size of the core-use areas; the largest turtle (84717) occupied the smallest core-use area $\left(13.4 \mathrm{~km}^{2}\right)$, and the smallest turtle (91387) occupied an intermediate-size core-use area $\left(21.2 \mathrm{~km}^{2}\right)$. Mean swim speed for all turtles during inter-nesting ranged from 1.2 to $1.7 \mathrm{~km} \mathrm{~h}^{-1}$ (Table 3). Based on the tagging data, turtles nesting on East Key did not access any other land areas (e.g. Loggerhead Key, the other main nesting beach in the Tortugas) during their time within the park. Thus, we observed nesting-site fidelity to East Key throughout their $\sim 3$ mo time period spent within the park.

Core-use areas were concentrated near East Key, but the area of $95 \%$ KDEs also overlapped with that of the RNA (Fig. 2). The site-fidelity test indicated that the observed turtle tracks and movements during inter-nesting were more constrained than randommovement paths (Table 3), implying a high-level of site fidelity in the satellite-tracking data for the inter-nesting period, in particular. Spatial analysis of the overlap of all 7 turtles' core-use areas revealed that spatially similar inter-nesting habitat was used in 2008 and 2009 around East Key (Fig. 2). Mean ( \pm SD) lidar-derived water depth for all loggerheads while they were in the park ranged from $7.7 \pm 5.1 \mathrm{~m}$ for the largest turtle (84717) to a maximum of $11.5 \pm 8.5 \mathrm{~m}$ for Turtle 89970 (Table 3).

The area of the 2008 overlap zone was $4.7 \mathrm{~km}^{2}$, which included a small patch of commonly used habitat to the north of East Key (Fig. 2, bottom-right panel). The area of the 2009 overlap zone was larger than that used by turtles tagged in 2008, at $7.5 \mathrm{~km}^{2}$. The area that was common to both 2008 and 2009 overlap zones was $4.2 \mathrm{~km}^{2}$. Finally, the approximate minimum and maximum distances from the center of East Key to the $50 \% \mathrm{KDE}$ boundaries were 0.5 to $1.9 \mathrm{~km}$ in 2008 and 1.2 to $2.3 \mathrm{~km}$ in 2009; the overlap of 2008 and 2009 core-use areas was 0.5 to $1.7 \mathrm{~km}$ from the center of East Key (Fig. 2).

Table 1. Caretta caretta. Satellite-tracking details for 7 females tagged in the Dry Tortugas (DRTO) and tracked during their internesting periods in 2008 and 2009. SCL-tip = straight carapace length to tip, KDE = kernel-density estimate. Bandwidth $\left(h_{C V}\right)$ was calculated using fixed-kernel least-squares cross validation

\begin{tabular}{|ccccccc|}
\hline Turtle & $\begin{array}{c}\text { SCL-tip } \\
(\mathrm{cm})\end{array}$ & $\begin{array}{c}\text { Tracking period } \\
(\text { inter-nesting period) } \\
\text { in DRTO }(\mathrm{m} / \mathrm{dd} / \mathrm{yy})\end{array}$ & $\begin{array}{c}\text { Time in } \\
\text { DRTO } \\
(\mathrm{d})\end{array}$ & $\begin{array}{c}\text { Mean } \pm \text { SD } \\
\text { swim speed } \\
\left(\mathrm{km} \mathrm{h}^{-1}\right)\end{array}$ & $\begin{array}{c}\text { Bandwidth } \\
\left(h_{\text {cv }}\right)\end{array}$ & $\begin{array}{c}\text { Area of } \\
50 \% \text { KDE } \\
\left(\mathrm{km}^{2}\right)\end{array}$ \\
\hline 84715 & 94.4 & $5 / 20 / 08-7 / 7 / 08$ & 42 & $1.4 \pm 1.2$ & 0.262 & 22.9 \\
84716 & 95.5 & $5 / 21 / 08-7 / 17 / 08$ & 50 & $1.2 \pm 1.1$ & 0.488 & 41.3 \\
84717 & 111.6 & $5 / 20 / 08-7 / 10 / 08$ & 51 & $1.6 \pm 1.4$ & 0.320 & 13.4 \\
89970 & 95.5 & $6 / 8 / 09-7 / 24 / 09$ & 21 & $1.7 \pm 1.2$ & 0.241 & 18.5 \\
91387 & 82.8 & $6 / 8 / 09-7 / 1 / 09$ & 19 & $1.7 \pm 1.3$ & 0.407 & 21.2 \\
95898 & 90.3 & $6 / 7 / 09-7 / 14 / 09$ & 30 & $1.4 \pm 1.1$ & 0.311 & 12.7 \\
95901 & 95.4 & $6 / 14 / 09-8 / 5 / 09$ & 29 & $1.5 \pm 1.2$ & 0.791 & 91.5 \\
\hline
\end{tabular}




\section{Benthic mapping and image analysis}

Fig. 3 shows representative images of the benthichabitat categories. Using shallow ATRIS, we mapped $16.916 \mathrm{~km}$ of transect lines in $3.12 \mathrm{~h}$ split between June 12 and 15, 2009 (Fig. 4). We acquired and permanently archived 53241 digital images, and later interpreted and analyzed 10274 of these images, based on the every-5th image setting and excluding those noted as unclassifiable; the spatial coverage of this mapping included $18530 \mathrm{~m}^{2}$ of seafloor. Interpretation of images took $\sim 6 \mathrm{~h}$, which equates to an approximate rate of $2 \mathrm{~s}$ image $^{-1}$. Images of either seagrass or rubble occurred most frequently, accounting for a combined $50.8 \%$ of the total, whereas senile reef was the least-represented habitat type $(10.4 \%$; Table 4$)$. Corresponding depths ranged from 4.9 to $19.0 \mathrm{~m}$ (mean $\pm \mathrm{SD}: 7.3 \pm 2.6 \mathrm{~m}$ ), exclusive of unclassifiable images. More than half of the images $(53 \%)$ were taken at water depths $<6 \mathrm{~m}$, and $90 \%$ of the images at depths $<8 \mathrm{~m}$. Over the range of collection depths, imaging distances ranged from 1.3 to $14.9 \mathrm{~m}$ (mean $\pm \mathrm{SD}: 3.0 \pm 1.5 \mathrm{~m}$ ), which means image spatial resolution varied between 0.0004 and $0.006 \mathrm{~m} \mathrm{pixel}^{-1}$. More than $50 \%$ of the identified seagrass in the mapped area lies north of East Key (Fig. 4, rows A-D), whereas most of the sand and rubble habitats occur to the west and south (Fig. 4, rows $\mathrm{E}-\mathrm{H})$. Among the identified senile-reef images, $81.3 \%$ occurs west of East Key. We also found that rubble was more-or-less evenly distributed throughout the 2008 commonly used core area. Qualitatively, long (order of $100+\mathrm{m}$ ) homogeneous segments of benthic cover tend to be separated by a series of short (order of $10+\mathrm{m}$ ) segments of different cover types.

In our quantitative assessment of habitat diversity, the spatial distribution of the 2 complementary indices (inverse of Simpson's index $H$ and dominance $D$, a modified Shannon index) showed that the region from East Key to the deep channel to its west exhibits minimal habitat diversity in terms of $H$. However, adjacent regions to the north and south have near-maxi-

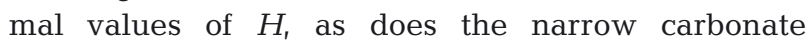
platform on the other side of the channel (Fig. 5, rows D-G, columns 2-4). Overlying the total number of extremely high-quality (e.g. LCs 3,2 , and 1) turtle observations per cell (Fig. 5) showed that the turtles were most often located on East Key (cross-hatched cells) or off its western shore (Fig. 5, rows E-F, columns 8-9). Values of $D$ were moderately high (0.4 to 0.5 ) in the area with high numbers of turtle locations and low to minimal ( 0.0 to 0.2$)$ for the adjacent regions to the north and south, as well as to the west across the channel.
Table 2. Caretta caretta. Nesting emergences inferred from satellite-tracking data during the inter-nesting interval, East Key, Dry Tortugas National Park

\begin{tabular}{|c|c|c|c|c|}
\hline Turtle & $\begin{array}{l}\text { Inferred } \\
\text { nesting } \\
\text { dates } \\
\text { (m/dd/yy) }\end{array}$ & $\begin{array}{l}\text { Inter- } \\
\text { nesting } \\
\text { interval } \\
\text { (d) }\end{array}$ & $\begin{array}{l}\text { Mean } \pm \text { SD } \\
\text { inter- } \\
\text { nesting } \\
\text { interval (d) }\end{array}$ & $\begin{array}{l}\text { Clutch } \\
\text { frequency } \\
\text { (nests } \\
\text { ind. }^{-1} \text { ) }\end{array}$ \\
\hline \multirow[t]{5}{*}{84715} & $5 / 20 / 08$ & 10 & \multirow[t]{5}{*}{$12.0 \pm 2.2$} & \multirow[t]{5}{*}{5} \\
\hline & $5 / 30 / 08$ & 15 & & \\
\hline & 6/14/08 & 11 & & \\
\hline & $6 / 25 / 08$ & 12 & & \\
\hline & 7/7/08 & & & \\
\hline \multirow[t]{6}{*}{84716} & $5 / 21 / 08$ & 12 & \multirow[t]{6}{*}{$11.4 \pm 2.1$} & \multirow[t]{6}{*}{6} \\
\hline & $6 / 2 / 08$ & 11 & & \\
\hline & 6/13/08 & 13 & & \\
\hline & 6/26/08 & 8 & & \\
\hline & $7 / 4 / 08$ & 13 & & \\
\hline & $7 / 17 / 08$ & & & \\
\hline \multirow[t]{5}{*}{84717} & $5 / 20 / 08$ & 14 & \multirow[t]{5}{*}{$12.8 \pm 1.0$} & \multirow[t]{5}{*}{5} \\
\hline & 6/3/08 & 12 & & \\
\hline & $6 / 15 / 08$ & 13 & & \\
\hline & $6 / 28 / 08$ & 12 & & \\
\hline & $7 / 10 / 08$ & & & \\
\hline \multirow[t]{5}{*}{89970} & 6/8/09 & 11 & \multirow[t]{5}{*}{$11.0 \pm 0.8$} & \multirow[t]{5}{*}{5} \\
\hline & 6/19/09 & 11 & & \\
\hline & 6/30/09 & 12 & & \\
\hline & $7 / 12 / 09$ & 10 & & \\
\hline & $7 / 22 / 09$ & & & \\
\hline \multirow[t]{3}{*}{91387} & 6/8/09 & 9 & \multirow{3}{*}{$11.0 \pm 2.8$} & \multirow[t]{3}{*}{3} \\
\hline & $6 / 17 / 09$ & 13 & & \\
\hline & 6/30/09 & & & \\
\hline \multirow[t]{4}{*}{95898} & 6/7/09 & 11 & \multirow[t]{4}{*}{$12.3 \pm 2.1$} & \multirow[t]{4}{*}{4} \\
\hline & 6/18/09 & 14 & & \\
\hline & 7/2/09 & 12 & & \\
\hline & $7 / 14 / 09$ & & & \\
\hline \multirow[t]{5}{*}{95901} & 6/14/09 & 10 & \multirow[t]{5}{*}{$11.6 \pm 1.9$} & \multirow[t]{5}{*}{5} \\
\hline & 6/27/09 & 13 & & \\
\hline & $7 / 10 / 09$ & 13 & & \\
\hline & $7 / 23 / 09$ & 13 & & \\
\hline & 8/1/09 & 9 & & \\
\hline
\end{tabular}

Table 3. Caretta caretta. Mean swim speed and light-detection and ranging (lidar) depths for loggerheads tagged on East Key in the Dry Tortugas (DRTO) during the inter-nesting period. In the site-fidelity test, $S$ is the proportion of the movement paths with higher mean-squared distance values from the center of activity. We used all filtered observations during each turtle's period in DRTO for the site-fidelity test

\begin{tabular}{|ccccc|}
\hline Year & Turtle & $\begin{array}{c}\text { Mean } \pm \text { SD } \\
\text { swim speed } \\
\left(\mathrm{km} \mathrm{h}^{-1}\right)\end{array}$ & $\begin{array}{c}\text { Mean } \pm \\
\text { SD lidar } \\
\text { depth }(\mathrm{m})\end{array}$ & $\begin{array}{c}\text { Site- } \\
\text { fidelity } \\
\text { test }(S)\end{array}$ \\
\hline 2008 & & & & \\
& 84715 & $1.4 \pm 1.2$ & $9.8 \pm 6.4$ & $>99.01$ \\
& 84716 & $1.2 \pm 1.1$ & $9.8 \pm 5.2$ & $>99.01$ \\
2009 & 84717 & $1.6 \pm 1.4$ & $7.7 \pm 5.1$ & $>99.01$ \\
& 89970 & $1.7 \pm 1.2$ & $11.5 \pm 8.5$ & $>97.03$ \\
& 91387 & $1.7 \pm 1.3$ & $7.6 \pm 4.6$ & $>80.20$ \\
& 95898 & $1.4 \pm 1.1$ & $9.6 \pm 5.9$ & $>99.01$ \\
& 95901 & $1.5 \pm 1.2$ & $9.5 \pm 6.4$ & $>99.01$ \\
\hline
\end{tabular}



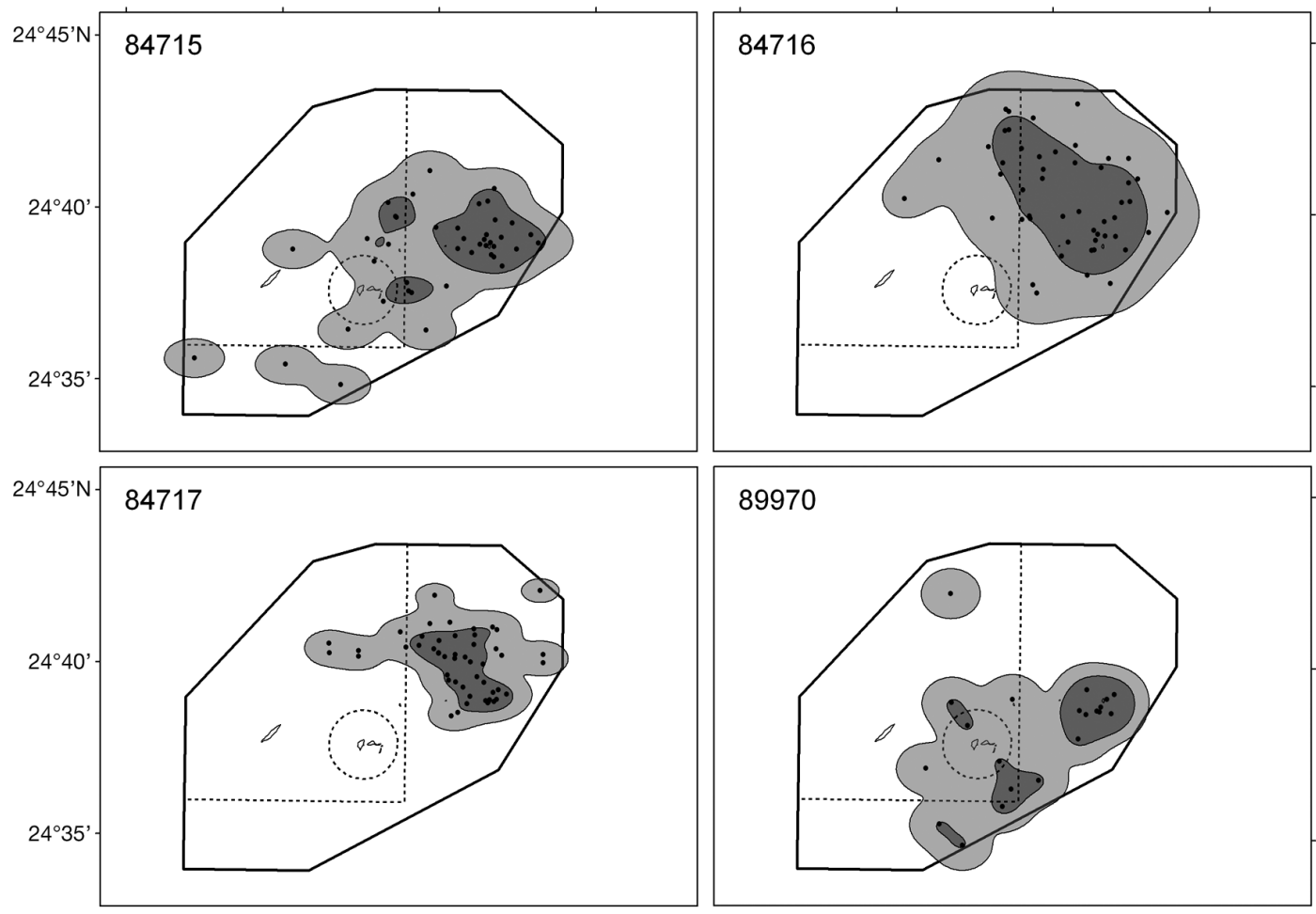

\section{0}
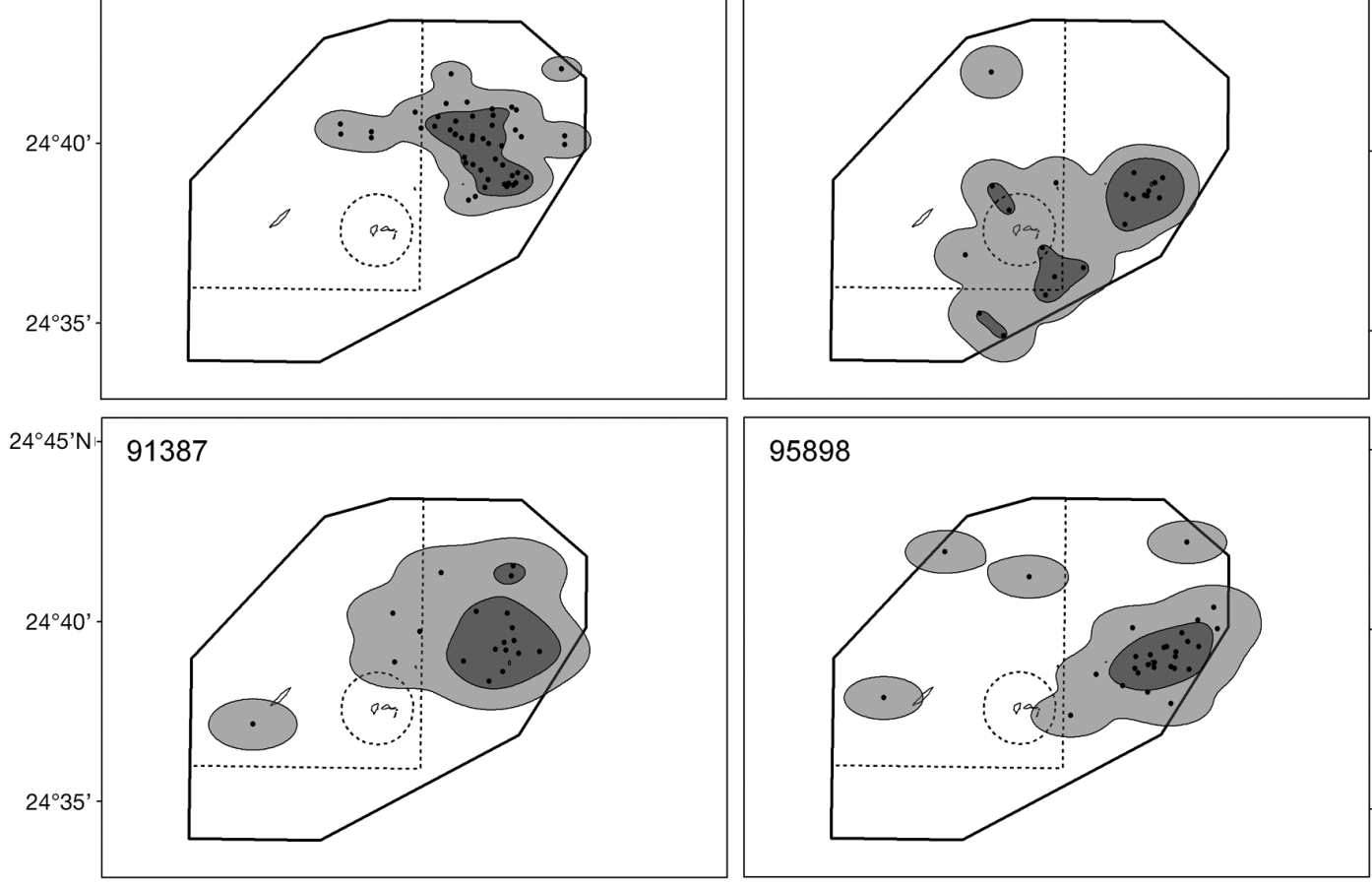

\section{8}
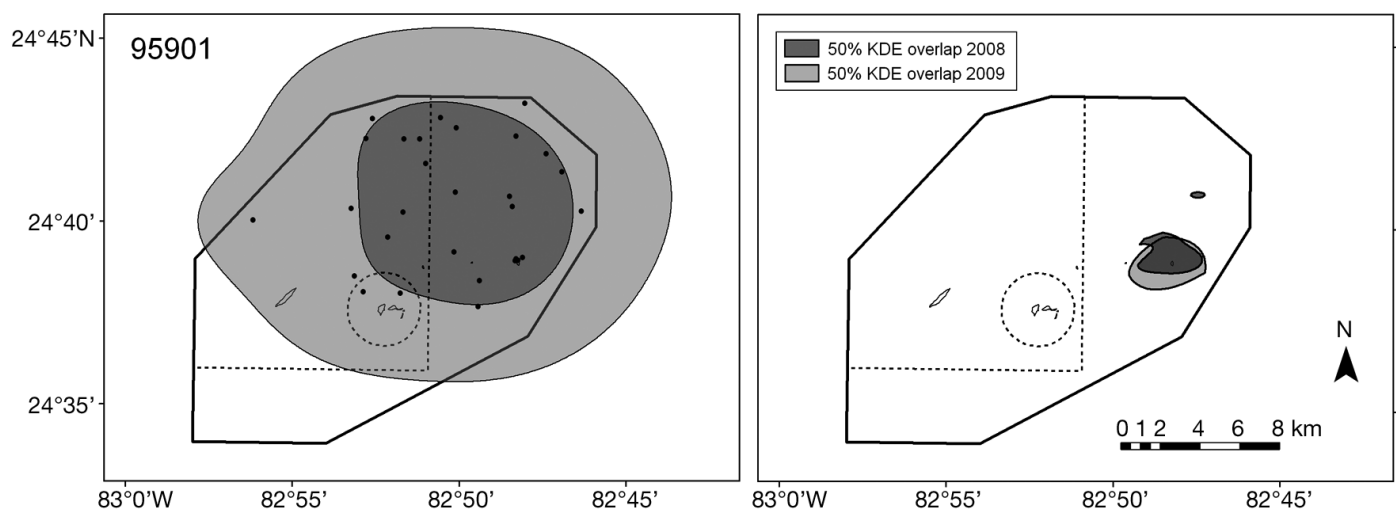

Fig. 2. Caretta caretta. Kernel-density estimate plots (KDEs) for Dry Tortugas loggerheads during the $\sim 3$ mo inter-nesting period when they are residents of the Tortugas. Each panel shows: turtle ID number; $95 \%$ KDE (light gray), which represents the general home range of each turtle during the inter-nesting period; $50 \% \mathrm{KDE}$ (dark gray), which represents the core area used during inter-nesting; and mean daily locations (•). Dry Tortugas National Park (solid) and Research Natural Area (dashed) boundaries are outlined (see Fig. 1). Turtles 84715, 84716, and 84717 were tagged in 2008; all others in 2009. The bottom-right panel depicts overlap zones of individual loggerhead 50 \% KDEs in 2008 and 2009 in the National Park. Note the consistent inter-annual use of habitat around East Key 

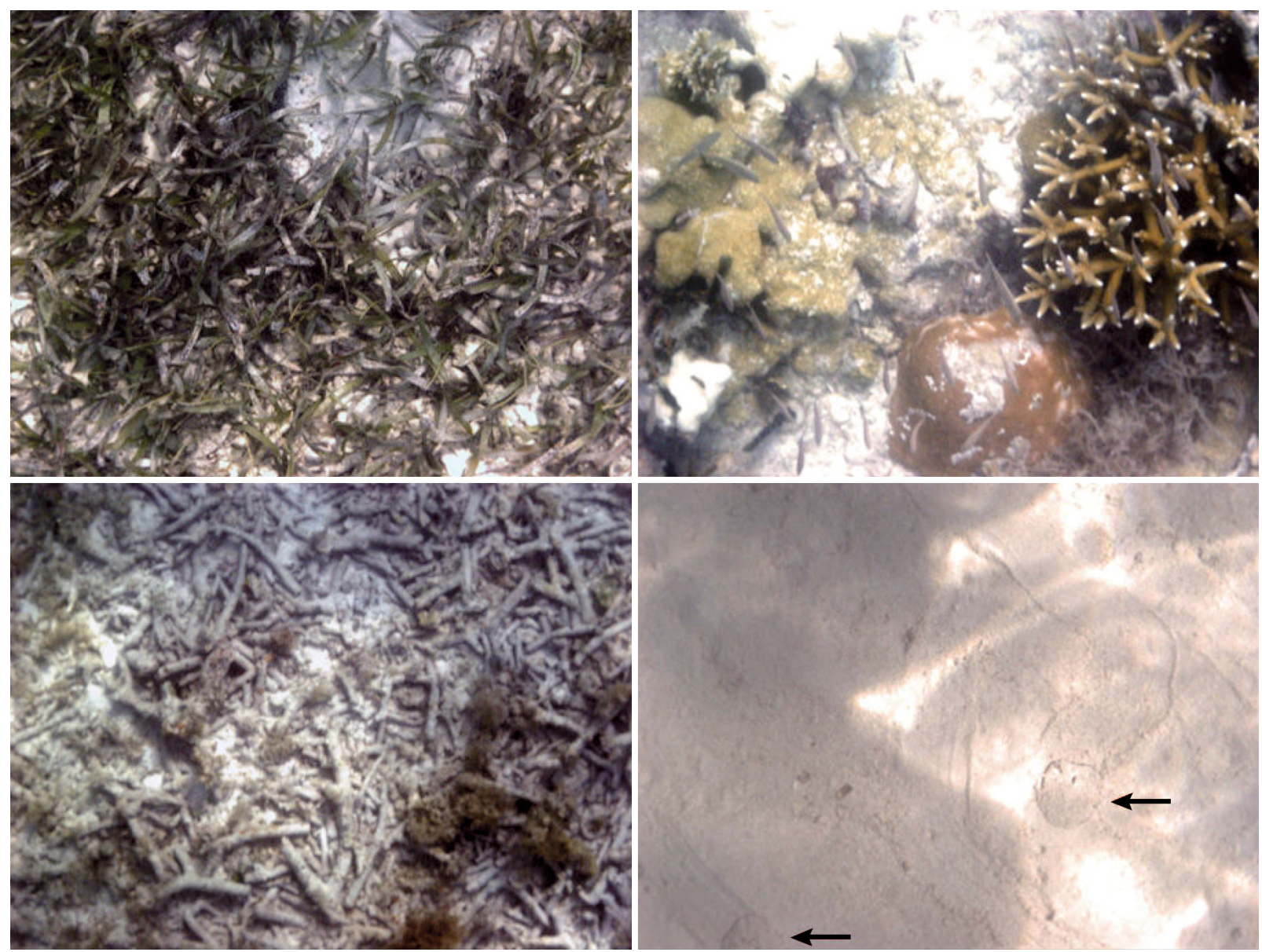

Fig. 3. Archetypal images for each substrate classification category. (A) Seagrass Thalassia testudinum. (B) Senile reef with identifiable colonies of the stinging coral Millepora alcicornis (top left corner), the encrusting zoanthid Palythoa caribraeorum (left, middle ), and staghorn coral Acropora cervicornis (right). Note school of scarids (parrotfishes). Also note areas devoid of pigmentation or tissue on the head coral. It is not known whether the bare areas were or are due to bleaching or disease. (C) Rubble consisting primarily of $A$. cervicornis sticks. (D) Sand with 2 live six-keyhole sand dollars Mellita sexiesperforata $(\longleftarrow)$. Note detail of their tracks

\section{DISCUSSION}

Our data indicate that loggerheads nesting on East Key use a spatially confined area during their reproductive period in the Dry Tortugas. All of the core-use areas were within $2.3 \mathrm{~km}$ of the nesting beach, supporting the finding of Schroeder et al. (2003) of a $5 \mathrm{~km}$ long loggerhead nesting-site fidelity range. Furthermore, loggerheads that used East Key accessed the nesting beach within the expected $\sim 2$ wk period constituting the inter-nesting interval. High-quality location data derived from satellite tracking revealed that tagged turtles nesting on East Key did not emerge on any other beach in the Dry Tortugas, indicating nestsite fidelity to the small (i.e. $\sim 400 \mathrm{~m}$ long $\times \sim 100 \mathrm{~m}$ wide) beach, and highlighting a concern about losing this critical habitat as a result of climate change-induced sea-level rise. Moreover, for these tagged loggerheads, most of the core-use areas were situated outside of the RNA. Because we observed only slight differences in the location and extent of these inter-nesting sites across individuals and years (e.g. Fig. 2), these particular regions near East Key seem to be preferred by loggerhead turtles and may offer the right mix of microhabitats necessary for endurance during the internesting period. In addition, extremely high-quality turtle-location data showed that turtles used the channel to the west of East Key, which may represent a bathymetric feature that provides a resting spot where turtles can minimize their energetic costs during this reproductive period.

Although we have defined a region repeatedly exploited by East Key loggerheads during internesting periods, the core-use areas for these turtles may not be predictive of where loggerheads nesting on other available beaches at DRTO (e.g. Loggerhead 


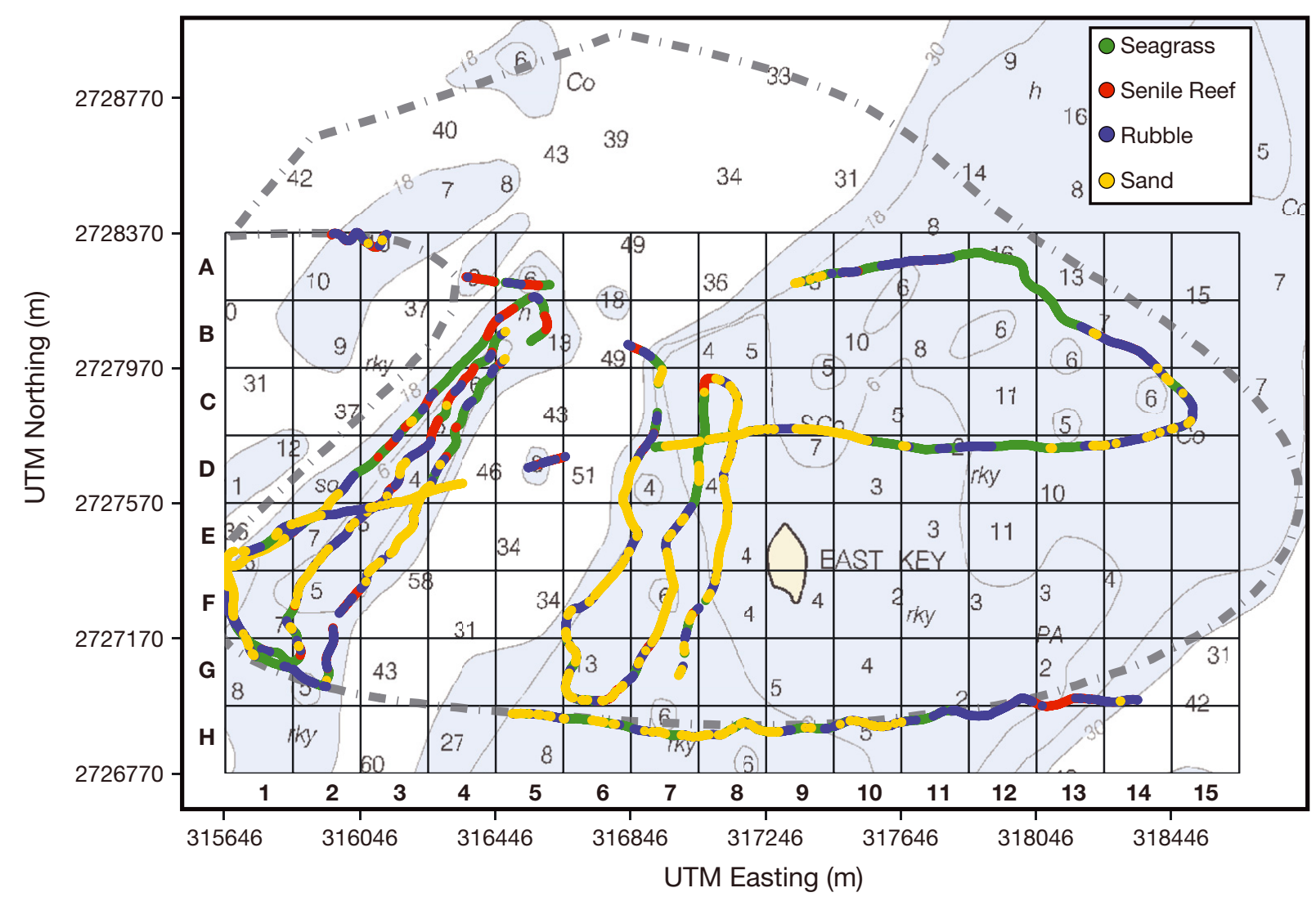

Fig. 4. Benthic mapping around East Key. Shallow-ATRIS transect lines are colored according to corresponding benthic habitat. Gaps occurred when images contained no discernible features. Scope of the survey was based on the $200850 \%$ kernel density plots (dashed-dotted gray line). The grid indicates the $200 \times 200 \mathrm{~m}$ cells used to bin the classification data for computing the habitat-diversity indices. The bolded letters and numbers facilitate referencing specific cells in the text. The light blue areas are shaded based on labeled depth contours, according to NOAA's charting protocol. The underlying map was excerpted from the free digital version of NOAA Raster Navigational Chart no. 11438, edition 13, available at www.charts.noaa.gov/RNCs/ RNCs.shtml. Depths on the NOAA map are in feet

Key) spend their inter-nesting time. The distance between the 2 main nesting beaches, East Key and Loggerhead Key, is $12 \mathrm{~km}$, and we did not see evidence in our tracking data that turtles nesting on East Key made any attempt to access or nest on Loggerhead Key.

Table 4. Caretta caretta. Image-classification scheme and corresponding percent cover of each benthic-habitat type within the study site, the 2008 core-use area for loggerheads in the Dry Tortugas

\begin{tabular}{|llc|}
\hline Class & \multicolumn{1}{c|}{ Criteria } & $\begin{array}{r}\% \text { Presence } \\
(\mathrm{N}=10274)\end{array}$ \\
\hline Unclassifiable & No discernible features & 20.5 \\
Seagrass & $\geq 75 \%$ coverage & 27.2 \\
Senile reef & Mixed community of & 10.4 \\
& living organisms with & \\
Rubble & $<50 \%$ live coral & 23.6 \\
Sand & $\geq 75 \%$ coverage & 18.3 \\
& & \\
& & \\
\end{tabular}

\section{Benthic mapping}

Previous inter-nesting studies on loggerheads provided little information on the benthic habitats occupied by turtles throughout their reproductive stage. Although the animal-borne camera plus TDR package used by Fuller et al. (2009) offers promise, the shortterm (i.e. 12 to $14 \mathrm{~d}$ ) nature of their deployment limits detection of differential habitats used throughout the $\sim 3$ to 4 mo long inter-nesting period.

Inter-nesting zones are just as important as the nesting beaches, because they provide shelter and possibly forage to turtles between nesting events. Given this significance, we included a high-resolution mapping component in the present study to characterize areas frequented by East Key loggerheads during their internesting period. The resultant habitat characterization, coupled with in-water turtle locations, reveals an interesting pattern. Although the $50 \%$ KDE spans the width of the carbonate platform supporting East Key (Fig. 4), the highest-quality turtle-location data show a clear 
Habitat Diversity (inverse Simpson index)

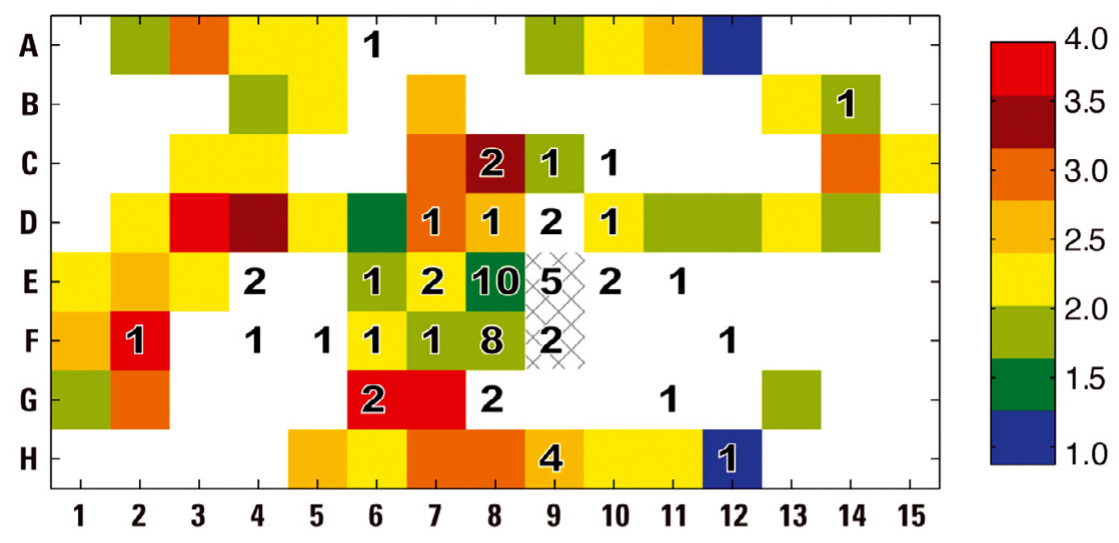

Dominance (modified Shannon index)

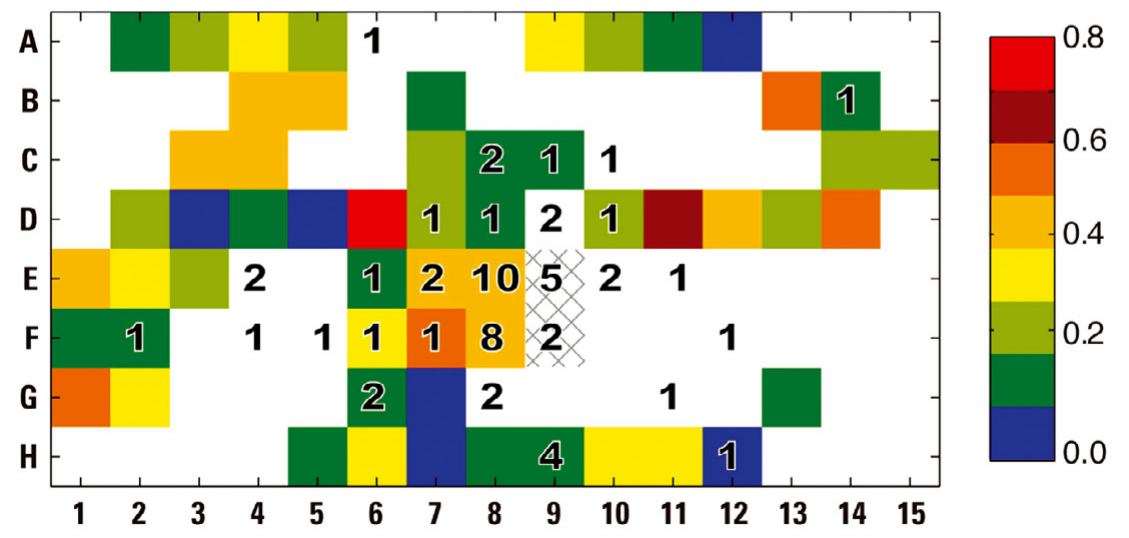

Fig. 5. Habitat-diversity indices. Both the inverse Simpson (upper panel) and modified Shannon (lower panel) indices were computed for non-overlapping, $200 \times 200 \mathrm{~m}$ cells defined by the grid in Fig. 4. Cells containing $<50$ classified shallow-ATRIS images were excluded from the analysis. The cross-hatched cells denote the location of East Key. Total number of turtle observations obtained via satellite tracking is indicated for each cell (black numbers). Letters and numbers along the axes facilitate referencing specific cells in the text. The spatial variability of these indices reflects changes in habitat diversity (inverse Simpson) and benthic-cover type (modified Shannon) at the $200 \mathrm{~m}$ scale throughout the study site

preference for proximity to both the island and nearby channel (Fig. 5, rows E-F, columns 6-9). This target area has low habitat diversity (low $H$, moderately high $D$ ) dominated by sand and rubble. However, it is nestled between regions with a relatively high diversity of habitats in near-equal proportions (high $H$, low $D$ ). In addition, nests were predominantly located on the western half of East Key, spanning the north-south extent of the island (K. M. Hart pers. obs.). Considered together, these findings indicate that the area to the west of East Key may serve as a corridor for loggerheads, providing ready access to the nesting beach, deep water, and the full range of habitat types present within the study site. The importance of deep channels for mature loggerheads has been shown by VanDolah \& Maier (1993) for Charleston Harbor, South Carolina, but not necessarily during the inter-nesting period.

Clearly, the loggerheads at the present study site could access deeper water by traveling east, north, or south of East Key; however, such transits would require swimming 600 to $>1000 \mathrm{~m}$, instead of $400 \mathrm{~m}$ through the western corridor. These alternative routes would impose an additional energy expense on animals already taxed by the nesting process. Moreover, our analysis of turtle movements showed that they were not random (Table 3). We argue that the turtles are optimizing their behavior and utilizing the path of least resistance proffered by the western corridor, a behavior hypothesized by Houghton et al. (2002).

\section{CONCLUSIONS}

Few prior studies have focused on characterizing movements and habitat use of loggerhead turtles during the inter-nesting period. Most recently, Schofield et al. $(2009,2010)$ have shown the potential of GPS tracking to illuminate even finer-scale habitat use dur- 
ing inter-nesting for Mediterranean loggerheads. Typically, prior emphasis has been on tracking females post-nesting to determine regional linkages between nesting beaches and foraging grounds. However, suitable nesting and inter-nesting habitats are critical components of not only reproductive success, but also for success of population-restoration efforts (National Marine Fisheries Service \& US Fish and Wildlife Service 2008, Schofield et al. 2010). Protecting these sites necessitates delineating their boundaries and characterizing benthic habitats contained therein. Toward this end, we have developed a method that melds state-of-the-art satellite tracking with rapid, highresolution imaging of the seafloor to identify and classify core-use areas for nesting loggerhead turtles. Although we focused on loggerheads in a US National Park, our technique is applicable to other marine animals and locales. Methodologically, our study highlights the benefits of coupling camera technologies and satellite telemetry to identify benthic characteristics of at-sea habitats favored by marine turtles and other organisms. Future coupling of Argos-linked Fastloc GPS tags (e.g. Witt et al. 2010) with ATRIS may prove even more useful for determining fine-scale turtle habitat use within this key inter-nesting time period. These approaches represent key examples of the maturation of satellite tracking as a discipline (Godley et al. 2008, Hart \& Hyrenbach 2009).

Using this novel marriage of techniques, we delineated the core-use areas of nesting loggerheads to a $\sim 3 \mathrm{~km}$ zone surrounding East Key, revealing strong fidelity to that island, and discovered a possible corridor used by these animals to transit to and from their upland nesting habitat. Both findings have direct implications for DRTO managers, especially given the current proposal for upgrading the status of loggerheads from threatened to endangered (US Fish and Wildlife Service \& NOAA 2010).

Resource assessments similar to ours should be performed prior to the creation of MPAs to ensure that critical habitat for threatened and endangered species receives appropriate priority for protection in the development of spatially explicit conservation plans. Finally, our results indicate that adaptive management of DRTO protected-area boundaries may be necessary to offer sufficient protection to loggerheads nesting on East Key during their residency in the park.

Acknowledgements. We are indebted to Captains C. 'Blue' Douglass, J. Douglass, and J. Spade of the National Park Service (NPS) for their assistance and lodging aboard the MV 'Fort Jefferson'. We acknowledge T. Gottshall, K. Nimmo, and M. Memory of the NPS for their general project assistance and support at DRTO. We thank A. Brame, M. Cherkiss, T. D. Hickey, G. Hill, B. Jeffery, C. Kellogg, I. Kuffner, K. Ludwig, J, Sanford, P. Thompson, and S. Traxler for help with ATRIS and/or catching and processing turtles. The USGS Coastal and Marine Geology Program, USGS Priority Ecosystem Studies Program, and the NPS provided funding for this project. We thank J. Luo, University of Miami, for access to DRTO lidar data. All research on loggerheads was conducted according to institutional and animal-care protocols and was authorized by Dry Tortugas Scientific Research Permit DRTO-2008-SCI-0008 and State of Florida Marine Turtle Permit 176 issued to K.M.H. ATRIS work was permitted under Dry Tortugas Scientific Research Permit DRTO-2009-SCI-0005 issued to D.G.Z. References to non-USGS products and services are provided for information only and do not constitute endorsement or warranty, expressed or implied, by the US Government, as to their suitability, content, usefulness, functioning, completeness, or accuracy.

\section{LITERATURE CITED}

Addison DS (1996) Caretta caretta (loggerhead sea turtle) nesting frequency. Herpetol Rev 27:76

Bartol SM, Musick JA (1998) Movements of adult female loggerhead sea turtles found nesting in Virginia. Final report to US Army Corps of Engineers, Norfolk, VA

$>$ Blumenthal JM, Solomon JL, Bell CD, Austin TJ and others (2006) Satellite tracking highlights the need for international cooperation in marine turtle management. Endang Species Res 2:51-61

Broderick AC, Coyne MS, Fuller WJ, Glen F, Godley BJ (2007) Fidelity and overwintering of sea turtles. Proc R Soc Lond B 274:1533-1538

Coyne MS, Godley BJ (2005) Satellite tracking and analysis tool (STAT): an integrated system for archiving, analyzing and mapping animal tracking data. Mar Ecol Prog Ser 301: $1-7$

Dodd CK, Byles R (2003) Post-nesting movements and behavior of loggerhead sea turtles (Caretta caretta) departing from East-Central Florida nesting beaches. Chelonian Conserv Biol 4:530-536

Environmental Systems Research Institute (ESRI) (2007) ArcGIS 9.3 GIS. Redlands, CA

Fossette S, Girard C, Bastian T, Calmettes B and others (2009) Thermal and trophic habitats of the leatherback turtle during the nesting season in French Guiana. J Exp Mar Biol Ecol 378:8-14

> Fuller WJ, Broderick AC, Hooker SK, Witt MJ, Godley BJ (2009) Insights into habitat utilization by green turtles (Chelonia mydas) during the inter-nesting period using animal-borne digital cameras. Mar Technol Soc J 43: $51-59$

Girard C, Tucker AD, Calmettes B (2009) Post-nesting migrations of loggerhead sea turtles in the Gulf of Mexico: dispersal in highly dynamic conditions. Mar Biol 156: 1827-1839

> Godley BJ, Broderick AC, Glen F, Hays GC (2003) Post-nesting movements and submergence patterns of loggerhead marine turtles in the Mediterranean assessed by satellite tracking. J Exp Mar Biol Ecol 287:119-134

> Godley BJ, Blumenthal JM, Broderick AC, Coyne MS, Godfrey MH, Hawkes LA, Witt MJ (2008) Satellite tracking of sea turtles: Where have we been and where do we go next? Endang Species Res 4:3-22

Hart KM, Fujisaki I (2010) Satellite tracking reveals habitat use by juvenile green sea turtles Chelonia mydas in the Everglades, Florida, USA. Endang Species Res 11: 221-232

Hart KM, Hyrenbach KD (2009) Satellite telemetry of marine 
megavertebrates: the coming of age of an experimental science. Endang Species Res 10:9-20

Hays GC, Webb PI, Hayes JP, Priede IG, French J (1991) Satellite tracking of a loggerhead turtle (Caretta caretta) in the Mediterranean. J Mar Biol Assoc UK 71:743-746

Hays GC, Åkesson S, Godley BJ, Luschi P, Santidrian P (2001) The implications of location accuracy for the interpretation of satellite-tracking data. Anim Behav 61:1035-1040

Hays GC, Broderick AC, Glen F, Godley BJ, Houghton JDR, Metcalfe JD (2002) Water temperature and inter-nesting intervals for loggerhead (Caretta caretta) and green (Chelonia mydas) sea turtles. J Therm Biol 27:429-432

Hooge PN, Eichenlaub B (2000) Animal movement extension to ArcView, version 2.0. US Geological Survey, Alaska Science Center - Biological Science Office, Anchorage, AK

Hooge PN, Eichenlaub W, Hooge ER (2001) Animal movement extension to ArcView, version 2.5. US Geological Survey, Alaska Biological Science Center - Biological Science Office, Anchorage, AK

Hopkins-Murphy SR, Owens DW, Murphy TM (2003) Ecology of immature loggerheads on foraging grounds and adults in internesting habitat in the eastern United States. In: Bolten $A B$, Witherington $B E$ (eds) Loggerhead sea turtles. Smithsonian Institution Press, Washington, DC, p 79-92

> Houghton JDR, Broderick AC, Godley BJ, Metcalfe JD, Hays GC (2002) Diving behaviour during the internesting interval for loggerhead turtles Caretta caretta nesting in Cyprus. Mar Ecol Prog Ser 227:63-70

Lenihan DJ (1997) The Tortuga Triangle. Nat Hist 106:36-41

Lidz BH, Hallock P (2000) Sedimentary petrology of a declining reef ecosystem, Florida reef tract (U.S.A.). J Coast Res 16:675-697

Lidz BH, Reich CD, Peterson RL, Shinn EA (2006) New maps, new information: coral reefs of the Florida Keys. J Coast Res 22:61-83

Lidz BH, Brock JC, Nagle D (2008) Utility of shallow-water ATRIS images in defining biogeologic processes and selfsimilarity in skeletal scleractinia, Florida reefs. J Coast Res 24:1320-1338

Limpus CJ, Miller JD, Parmenter CJ, Reimer D, McLahan N, Webb R (1992) Migration of green (Chelonia mydas) and loggerhead (Caretta caretta) turtles to and from eastern Australian rookeries. Wildl Res 19:347-358

Mallinson D, Hine A, Hallock P, Locker S and others (2003) Development of small carbonate banks on the south Florida platform margin: response to sea level and climate change. Mar Geol 199:45-63

Mansfield KL, Saba VS, Kenaith JA, Musick JA (2009) Satellite tracking reveals a dichotomy in migration strategies among juvenile loggerhead turtles in the Northwest Atlantic. Mar Biol 156:2555-2570

Murphy TM, Hopkins SR (1981) Sonic and radio tracking of nesting Caretta caretta. In: Hopkins SR, Murphy TM (eds) Reproductive ecology of Caretta caretta in South Carolina. Study completion report to US Fish and Wildlife Service. South Carolina Wildlife and Marine Resources Department, Charleston, SC, p 5-38

National Marine Fisheries Service (2010) Fisheries of the Caribbean, Gulf of Mexico, and South Atlantic; reef fish fishery of the Gulf of Mexico; Amendment 31. Fed Regist 75:2469-2474

National Marine Fisheries Service \& US Fish and Wildlife Service (2008) Recovery plan for the Northwest Atlantic population of loggerhead sea turtle (Caretta caretta), 2nd revision. National Marine Fisheries Service, Silver Spring, MD

National Marine Fisheries Service Southeast Fisheries Sci- ence Center (2008) Sea turtle research techniques manual. NOAA Tech Memo NMFS-SEFSC-579. NOAA, Southeast Fisheries Science Center, Miami, FL

National Park Service (NPS) (2006) Dry Tortugas National Park-special regulations. Fed Regist 71:76154-76166

O'Neill RV, Krummel JR, Gardner RH, Sugihara G and others (1988) Indices of landscape pattern. Landscape Ecol 1: 153-162

Plotkin PT (2003) Adult migrations and habitat use. In: Lutz PL, Musick JA, Wyneken J (eds) The biology of sea turtles. CRC Press, Boca Raton, FL, p 225-241

> Plotkin PT, Spotila JR (2002) Post-nesting migrations of loggerhead turtles Caretta caretta from Georgia, U.S.A.: conservation implications for a genetically distinct subpopulation. Oryx 36:396-399

Reardon RT (2000) Annual report - 2000 season. Dry Tortugas National Park Sea Turtle Monitoring Program, Dry Tortugas, FL

Ricklefs RE, Lovette IJ (1999) The roles of island area per se and habitat diversity in the species-area relationships of four Lesser Antillean faunal groups. J Anim Ecol 68: $1142-1160$

Rodgers AR, Carr AP, Smith L, Kie JG (2005) HRT: home range tools for ArcGIS. Ontario Ministry of Natural Resources, Centre for Northern Forest Ecosystem Research, Thunder Bay

SAS Institute (1996) A guide to statistical and data analysis using JMP and JMP IN software. Duxbury Press, Belmont, NY

Sato K, Matsuzawa Y, Tanaka H, Bando T, Minimikawa S, Sakamoto W, Naito Y (1998) Internesting intervals for loggerhead turtles, Caretta caretta, and green turtles, Chelonia mydas, are affected by temperature. Can J Zool 76:1651-1662

Schofield G, Bishop CM, MacLean G, Brown P and others (2007) Novel GPS tracking of sea turtles as a tool for conservation management. J Exp Mar Biol Ecol 347:58-68

Schofield G, Lilley MKS, Bishop CM, Brown P and others (2009) Conservation hotspots: implications of intense spatial area use by breeding male and female loggerheads at the Mediterranean's largest rookery. Endang Species Res 10:191-202

> Schofield G, Hobson VJ, Lilley MKS, Katselidis KA, Bishop CM, Brown P, Hays GC (2010) Inter-annual variability in the home range of breeding turtles: implications for current and future conservation management. Biol Conserv 143:722-730

Schroeder BA, Foley AM, Bagley DA (2003) Nesting patterns, reproductive migrations, and adult foraging areas of loggerhead turtles. In: Bolten AB, Witherington BE (eds) Loggerhead sea turtles. Smithsonian Institution Press, Washington, DC, p 114-124

Seaman DE, Powell RA (1996) An evaluation of the accuracy of kernel density estimators for home range analysis. Ecology 77:2075-2085

Seminoff JA, Resendiz A, Nichols WJ (2002) Home range of green turtles Chelonia mydas at a coastal foraging area in the Gulf of California, Mexico. Mar Ecol Prog Ser 242: $253-265$

Seminoff JA, Zárate P, Coyne M, Foley DG, Parker D, Lyon BN, Dutton PH (2008) Post-nesting migrations of Galápagos green turtles Chelonia mydas in relation to oceanographic conditions: integrating satellite telemetry with remotely sensed ocean data. Endang Species Res 4:57-72

Seney E, Landry AM Jr (2008) Satellite telemetry and management of Kemp's ridley sea turtles nesting on the upper Texas coast. Endang Species Res 4:73-84 
Stoneburner DL (1982) Satellite telemetry of loggerhead sea turtle movement in the Georgia Bight. Copeia 1982: 400-408

Tucker AD (2010) Nest site fidelity and clutch frequency of loggerhead turtles are better elucidated by satellite telemetry than by nocturnal tagging efforts: implications for stock estimation. J Exp Mar Biol Ecol 383:48-55

US Fish and Wildlife Service \& NOAA (2010) Endangered and threatened species; proposed listing of nine distinct population segments of loggerhead sea turtles as endangered or threatened. Fed Regist 75:12598-12656

Van Houtan KS, Pimm SL (2006) Assessment of the Dry Tortugas National Park sea turtle monitoring program 1982-2006: ecological trends and conservation recommendations. National Park Service, Homestead, FL, USA

VanDolah RF, Maier PP (1993) The distribution of loggerhead turtles (Caretta caretta) in the entrance channel of Charleston Harbor, South Carolina, USA. J Coast Res 9: 1004-1012

Vincent C, McConnell BJ, Ridoux V, Fedak MA (2002) Assessment of Argos location accuracy from satellite tags deployed on captive gray seals. Mar Mamm Sci 18: 156-166

White GC, Garrott RA (1990) Analysis of wildlife radiotracking data. Academic Press, New York, NY

Witherington B, Kubilis P, Brost B, Meylan A (2009) Decreas-

Editorial responsibility: Hans Heinrich Janssen,

Oldendorf/Luhe, Germany ing annual nest counts in a globally important loggerhead sea turtle population. Ecol Appl 19:30-54

Witt MJ, Broderick AC, Coyne MS, Formia A and others (2008) Satellite tracking highlights difficulties in the design of effective protected areas for critically endangered leatherback turtles Dermochelys coriacea during the inter-nesting period. Oryx 42:296-300

Witt MJ, Akesson S, Broderick AC, Coyne MS and others (2010) Assessing accuracy and utility of satellite-tracking data using Argos-linked astloc-GPS. Anim Behav 80: $571-581$

Worton BJ (1987) A review of models of home range for animal movement. Ecol Modell 38:277-298

> Worton BJ (1989) Kernel methods for estimating the utilization distribution in home-range studies. Ecology 70 : 164-168

Worton BJ (1995) Using Monte Carlo simulation to evaluate kernel-based home range estimators. J Wildl Manag 59: 794-800

Zawada DG, Thompson PR, Butcher J (2008) A new towed platform for the unobtrusive surveying of benthic habitats and organisms. Rev Biol Trop 56:51-63

> Zbinden JA, Aebisher A, Margaritoulis D, Arlettaz R (2007) Insights into the management of sea turtle internesting area through satellite telemetry. Biol Conserv 137: $157-162$

Submitted: April 13, 2010; Accepted: September 27, 2010 Proofs received from author(s): November 6, 2010 